\title{
GERAKAN PENCEGAHAN STUNTING MELALUI PEMBERDAYAAN MASYARAKAT DI KECAMATAN JATINANGOR KABUPATEN SUMEDANG
}

\author{
Sri Astuti', Ginna Megawati ${ }^{1}$, dan Samson CMS². \\ ${ }^{1}$ Departemen Ilmu Kesehatan Masyarakat, Fakultas Kedokteran, Universitas Padjadjaran, \\ ${ }^{2}$ Fakultas Ilmu Komunikasi Universitas Padjadjaran \\ E-mail: sriastuti29a@gmail.com
}

\begin{abstract}
ABSTRAK. Stunting merujuk pada kondisi tinggi anak yang lebih pendek dari tinggi badan seumurannya, yang disebabkan kekurangan asupan gizi dalam waktu lama pada masa 1000 hari pertama kehidupan (HPK). Ketika dewasa, anak rentan terhadap serangan penyakit tidak menular seperti jantung, stroke, diabetes, ataupun gagal ginjal; menghambat bonus demografis Indonesia dimana rasio penduduk usia tidak bekerja terhadap penduduk usia kerja menurun; ancaman pengurangan tingkat intelejensi sebesar 5-11 poin. Selain faktor gizi, stunting disebabkan karena kurangnya pengetahuan masyarakat terutama, ibu hamil, ibu balita dan kader posyandu tentang stunting. Tujuan pemberdayaan masyarakat ini adalah mencegah kejadian stunting melalui pelatihan kader posyandu dan keterlibatan masyarakat pada event Hari Kesehatan Nasional ke 54. Metode kegiatan adalah cross sectional dan partisipasi masyarakat. Populasi adalah kader posyandu, Kepala Puskesmas Jatinangor dan jajarannya, Camat Jatinangor dan jajarannya. Sampel adalah kader posyandu sebanyak 50 orang di wilayah kerja Puskesmas Jatinangor Kabupaten Sumedang, dilaksanakan pada bulan November 2018. Hasil penelitian melalui pelatihan kader posyandu, didapatkan pengetahuan terbanyak cukup (40\%). Hasil event HKN ke 54 tersosialisasi pencegahan stunting melalui berbagai media komunikasi, dan ditandatanganinya komitmen pencegahan stunting di wilayah kecamatan Jatinangor. Simpulan pada penelitian ini bahwa gerakan pencegahan stunting melalui pelatihan meningkatkan pengetahuan kader posyandu dan melalui event HKN meningkatkan pemberdayaan masyarakat.
\end{abstract}

Kata kunci: kader posyandu; pencegahan; pemberdayaan masyarakat; stunting

ABSTRACT. Stunting refers to a child's shorter body height compared to his/her peers, which is caused by chronic malnutrition on the first 1000 days of life (FDL). When the child grows up, the child will be susceptible in contracting some diseases such as heart diseases, stroke, diabetes, or kidney failure; it hampers Indonesia's demographic bonus in which unemployed age people to employed age people ratio decreases; a threat in decreased intelligence level by 5-11 points. Aside from nutritional factors, stunting is caused by the community's poor knowledge, especially in pregnant women, toddler's mother, and posyandu volunteers regarding stunting. This community empowerment aims to prevent stunting incidence by training posyandu volunteers and community involvement on the $5^{\text {th }}$ National Health Day event. The method of this study is cross-sectional and community's participation. The population was posyandu volunteers, the Head of Puskesmas Jatinangor and his staffs, the Head of Jatinangor Subdistrict and his staffs. The samples were 50 posyandu volunteers on the working area of Puskesmas Jatinangor, Sumedang Regency, and it was held on November 2018. The results were through training of posyandu volunteers, their knowledge was adequate (40\%). From the $54^{\text {th }}$ National Health Day, stunting prevention was socialized through various communication media, and commitment to prevent stunting on Jatinangor subdistrict had been signed. The conclusion from this study that the stunting prevention movement by training enhances knowledge of posyandu volunteers and increases community empowerment.

Key words: community empowerment; posyandu cadres; prevention; stunting

\section{PENDAHULUAN}

Di negara berkembang stunting menjadi masalah kesehatan masyarakat yang serius dan prevalensinya tetap tinggi. Stunting disebabkan kekurangan asupan gizi dalam waktu lama pada masa 1000 hari pertama kehidupan (HPK) yang merupakan masa kritis. Balita setelah diukur panjang atau tinggi badan menurut umurnya, bila dibandingkan dengan standar baku WHO-MGRS (Multicentre Growth Reference Study) tahun 2005, nilai z-scorenya kurang dari -2SD dikatagorikan pendek, dan dikategorikan sangat pendek jika nilai z-scorenya kurang dari -3SD. (Kementrian Kesehatan RI, 2016)

Data Riset Kesehatan Dasar (Kemenkes, 2013) tahun 2013 tentang status gizi balita pendek (pendek dan sangat pendek) di Indonesia tahun 2013 adalah 37,2\%, jika dibandingkan tahun $2010(35,6 \%)$ dan tahun 2007 $(36,8 \%)$ tidak menunjukkan penurunan atau perbaikan yang signifikan, sementara menurut Dinas Kesehatan, jumlah balita pendek di Jawa Barat sebesar 29,2\%.
Jumlah balita pendek di Kabupaten Sumedang pun tercatat sebesar $41.08 \%$.

Asupan gizi yang dibutuhkan untuk mencegah stunting berupa asupan gizi yang baik saat hamil, konsumsi tablet penambah darah yang cukup saat hamil, pemberian ASI kepada anak selama 6 bulan pertama, dan dilanjutkan dengan makanan pendamping ASI yang tepat sampai anak berusia 2 tahun. Faktor-faktor lain yang berpengaruh terhadap kejadian stunting adalah kemampuan tenaga kesehatan dalam mendeteksi kondisi stunting sejak dini, kebersihan air dan lingkungan, pola pengasuhan anak, tempat persalinan dan genetik.

Anak-anak pendek menghadapi risiko yang lebih besar untuk tumbuh menjadi orang dewasa yang kurang berpendidikan, miskin, kurang sehat dan lebih rentan terhadap penyakit tidak menular. Anak pendek merupakan prediktor buruknya kualitas sumber daya manusia, yang selanjutnya menurunkan kemampuan produktif suatu bangsa di masa yang akan datang (Kemenkes, 2012). 
Kurangnya keterlibatan petugas kesehatan dengan para ibu dalam memberikan promosi nutrisi selama kehamilan, memberikan dampak antara lain terhadap pengetahuan ibu dan kesehatan ibu dan anak (Arrish, Yeatman, \&Williamson, 2017). Oleh karenanya diperlukan upaya pencegahan terjadinya stunting pada balita baik secara langsung (intervensi gizi spesifik) maupun secara tidak langsung yang melibatkan lintas sektor dan masyarakat dalam penyediaan pangan, air bersih dan sanitasi, penangulangan kemiskinan, pendidikan, sosial dan sebagainya (Kementrian Kesehatan RI, 2016) .

Data stunting di wilayah kerja Puskesmas Jatinangor sebesar 19,23\%. Menurut Bidan di Desa Kecamatan Jatinangor Kabupaten Sumedang, yang dilakukan pada balita stunting yaitu memberikan konseling pada ibu balita tentang pemberian makanan, rangsangan motorik, dan bekerjasama dengan petugas Gizi Puskesmas. Kader posyandu belum pernah memberikan penyuluhan pencegahan stunting di posyandu karena tidak tahu mengenai stunting, padahal kader posyandu mempunyai peran penting dalam memberikan informasi kepada masyarkat, khususnya tentang kesehatan pada ibu balita. Kader posyandu juga melakukan kerjasama dengan petugas kesehatan dan lintas sektor dalam upaya meningkatkan kegiatan posyandu, meningkatkan kunjungan masyarakat. Upaya yang dapat dilakukan oleh kader posyandu berkaitan dengan intervensi pencegahan stunting adalah memantau pertumbuhan balita di posyandu, karena itu merupakan upaya yang strategis untuk mendeteksi secara dini terjadinya gangguan pertumbuhan. Penanganan stunting merupakan prioritas pembangunan nasional melalui Rencana Aksi Nasional Gizi dan Ketahanan Pangan, penyelenggaraan dan pemberdayaan masyarakat dalam promosi kesehatan dan gerakan masyarakat hidup sehat termasuk prioritas dana desa. Upaya pemerintah lainnnya melalui media masa, komunikasi pada keluarga dan advokasi.

Berdasarkan permasalahan di atas, kami tim dosen Unpad melakukan pengabdian pada masyarakat bertujuan untuk meningkatkan pengetahuan kader posyandu tentang pencegahan stunting melalui promosi kesehatan dengan media kartu integrating card dan gerakan pencegahan stunting pada event Hari Kesehatan Nasional ke 54 bekerja sama dengan Puskesmas Jatinangor Kabupaten Sumedang

\section{METODE}

Metode pelaksanaan dalam kegiatan pemberdayaan masyarakat ini adalah cross-sectional dan partisipasi masyarakat. Populasi adalah kader posyandu, Kepala Puskesmas, bidan Puskesmas, bidan desa dan staff Puskesmas Jatinangor, Camat Jatinanngor beserta jajarannya, Dinas Kesehatan Kabupaten Sumedang, Kepala Desa Cikeruh danjajarannya, Katua Penggerak PKK Kecamatan Jatinangor, warga masyarakat Kecamatan Jatinangor.
Kegiatan gerakan pencegahan stunting dilakukan meliputi pelatihan kader posyandu dan Gerakan upaya pencegahan stunting. Pelatihan kader posyandu sebanyak 50 orang untuk mendapatkan data pengetahuan setelah dilakukan promosi kesehatan menggunakan media kartu. Data dianalisis dengan distribusi frekuensi. Dilaksanakan pada bulan November 2018 di Wilayah kerja Puskesmas Jatinangor Kecamatan Jatinangor Kabupaten Sumedang. Penelitian ini sudah mendapatkan ijin etik penelitian dari Fakultas Kedokteran Universitas Padjadjaran dengan No. 449/UN6.KEP/EC/2018.

\section{HASIL DAN PEMBAHASAN}

\section{A. Hasil pelaksanaan kegiatan}

a. Promosi pencegahan stunting menggunakan media integrating card kepada kader posyandu sebanyak 50 orang yang mengisi kuesioner secara lengkap, disajikan pada tabel berikut

Tabel 1. Pengetahuan kader posyandu pada pelatihan penggunaan media kartu Integrating pencegahan stunting

\begin{tabular}{ccc}
\hline Pengetahuan & $\begin{array}{c}\text { Sebelum } \\
\text { intervensi } \\
\mathrm{n}(\%)\end{array}$ & $\begin{array}{c}\text { Sesudah intervensi } \\
\mathrm{n}(\%)\end{array}$ \\
\hline Baik & $28(56)$ & $26(52)$ \\
Cukup & $12(24)$ & $20(40)$ \\
Kurang & $10(20)$ & $4(8)$ \\
Total & $50(100)$ & $50(100)$ \\
\hline
\end{tabular}

Berdasarkan tabel 1 bahwa sebelum pretes pengetahuan kader masih terdapat yang kurang (20\%), setelah mendapat promosi dengan bermain kartu, pengetahuan yang kurang menurun (10\%).

b. Pelaksanaan gerakan pencegahan stunting pada event Hari Kesehatan Nasional (HKN) ke 54 wilayah kerja PKM Jatinangor Kecamatan Jatinangor

1) Dilaksanakan bertempat di GOR Cikeruh, dihadiri oleh peserta: Perwakilan dari Dinas Kesehatan Kabupaten Sumedang, Kepala PKM Jatinangor beserta jajarannya, para bidan desa, Camat Jatinangor beserta jajarannya, Ketua Penggerak PKK Kecamatan Jatinangor, Kepala Desa beserta jajarannya, para kader posyandu, warga desa Cikeruh.

2) Hasil Kegiatan

a) Pada gerakan pencegahan stunting dilakukan promosi pencegahan stunting, sosialisasi penggunaan kartu integrating untuk promosi baik oleh tenaga kesehatan, kader posyandu dan ibu balita.

b) Komitmen dari stakeholder baik lintas program maupun lintas sektor untuk mencegah stunting di Kecamatan Jatinangor yang dituangkan dalam kesepakatan bersama 
c) Penyerahan banner promosi stunting kepada Camat Jatinangor sebagai salah satu media promosi di kantor kecamatan

Dikemukakan dalam Surat keputusan Menkes RI (Kemenkes, 2007) bahwa promosi kesehatan adalah upaya untuk meningkatkan kemampuan masyarakat melalui pembelajaran dari, oleh, untuk, dan bersama masyarakat, yang dapat mengembangkan kegiatan bersumber daya masyarakat sesuai kondisi sosial budaya setempat.

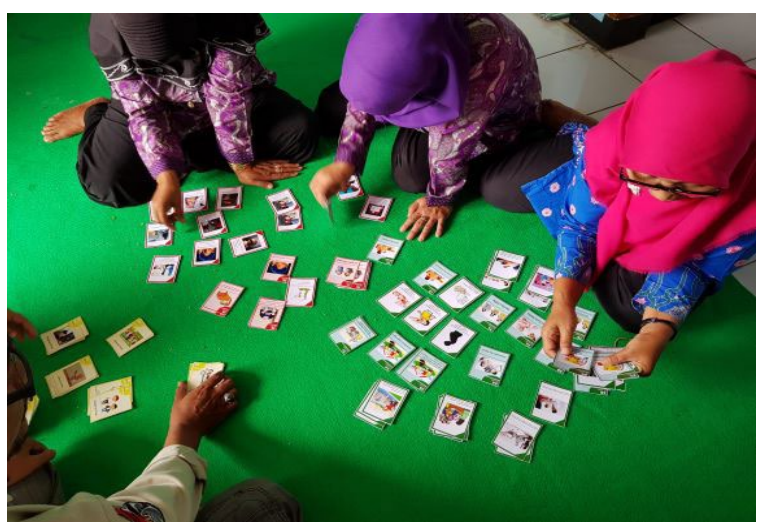

Gambar 1. Foto promosi kesehatan pencegahan stunting menggunakan media kartu pada pelatihan kader posyandu

Hasil olah data pada tabel 1 dari data distribusi frekuensi didapatkan hasil setelah mendapat promosi dengan bermain kartu, pengetahuan kader yang kurang menurun (10\%) yang sebelumnya $20 \%$. Hal ini sejalan dengan hasil penelitian Erna K dkk (Kusumawati, Rahardjo, \& Sari, 2015) bahwa dalam mencegah stunting diperlukan pemberdayaan masyarakat dengan meningkatkan peran dan fungsi kader posyandu.

Terkait peran kader posyandu adalah men-dapatkan berbagai informasi kesehatan lebih dahulu dan lebih lengkap. Ikut berperan secara nyata dalam perkembangan tumbuh kembang anak balita dan kesehatan ibu. Salah satu fungsi posyandu adalah sebagai media promosi kesehatan dan gizi, pemantauan pertumbuhan balita. Promosi kesehatan adalah suatu kegiatan atau usaha menyampaikan informasi kesehatan kepada masyarakat sehingga dapat meningkatkan pengetahuan tentang kesehatan yang lebih baik. Oleh karena itu, pemberian informasi tentang pencegahan stunting bagi kader posyandu sangatlah penting, karena dengan begitu para kader memiliki bekal untuk melaksanakan perannya dalam memberikan penyuluhan kepada para ibu di posyandu, sehingga diharapkan kejadian stunting dapat berkurang.(Maywita, 2018) Posyandu berhubungan dengan pengetahuan dan kejadian stunting. Posyandu merupakan sumber pengetahuan terkait stunting, mengingat di Posyandu dilakukan penimbangan berat badan setiap bulan dan pengukuran tinggi badan pada bayi dan balita setiap 6 bulan sekali yang hasilnya dimasukkan pada grafik tinggi badan menurut umur pada buku KIA, sehingga dapat terdeteksi kejadian stunting. Penting keterlibatan bidan desa dan petugas gizi Puskesmas untuk pengisian grafik tinggi badan sesuai umur bayi dan balita sehingga kader posyandu dan ibu balita memahami pertumbuhan tinggi badan bayi dan balitanya.

Pada penelitian ini didapatkan gambaran bahwa kader posyandu hampir seluruhnya menyatakan media kartu integrating efektif, dengan alasan lebih mudah dipahami, menarik, belajar memahami tentang stunting lebih mudah dengan adanya gambar dan penjelasannya. Hasil penelitian dapat meningkatkan pengetahuan kader melalui media promosi kartu Integrating. Kartu merupakan media informasi yang berinteraksi dengan komunikasi, dan antar individu dapat berinteraksi.

Gerakan pencegahan stunting pada event HKN ke 54, merupakan salah satu upaya intervensi lintas sektor yang melibatkan stakeholder. Melalui penandatanganan komitmen dari Camat dan jajarannya, juga Kepala Puskesmas dan penulis adalah merupakan kepedulian dalam pencegahan stunting. Hal ini sejalan dengan upaya yang dilakukan pemerintah bahwa pencegahan stunting dapat dilakukan melalui komunikasi masa, selain pada media masa.

Kegiatan Gerakan Pencegahan Stunting pada event $\mathrm{HKN}$ ke 54 sejalan dengan Gerakan Masyarakat Hidup Sehat (GERMAS) dan penanganan stunting yang menjadi prioritas pemerintah diperkuat dengan telah dikeluarkannya Permendesa No. 19 Tahun 2017 tentang Prioritas Penggunaan Dana Desa, tahun 2018, penanganan stunting diprioritaskan pada 1000 desa di 100 kabupaten/ kota di seluruh Indonesia, dengan penanganan melalui intervensi spesifik dan sensitif

Simpulan dalam penelitian ini gerakan pencegahan stunting melalui pelatihan meningkatkan pengetahuan kader posyandu dan melalui event HKN meningkatkan pemberdayaan masyarakat. Saran untuk bidan desa dan stake holder, promosi kesehatan perlu dilakukan secara berkesinambungan untuk lebih meningkatkan pengetahuan kader dan masyarakat didukung oleh bina suasana, advokasi serta dilandasi oleh semaangat kemitraan sebagai strategi pemberdayaan masyarakat. yang akhirnya kejadian stunting dapat dicegah, sehingga melahirkan generasi emas bangsa Indonesia.(Kementrian Desa, 2017)

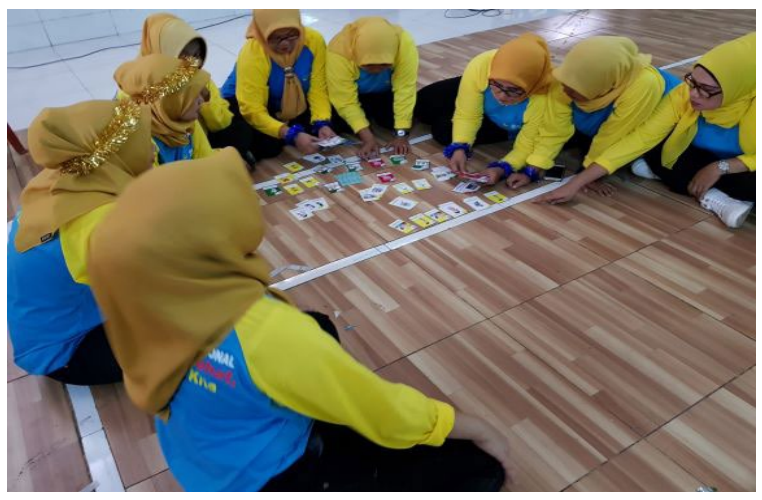

Gambar 2. Sosialisasi media kartu integrating pencegahan stunting kepada peserta $\mathrm{HKN}$ 


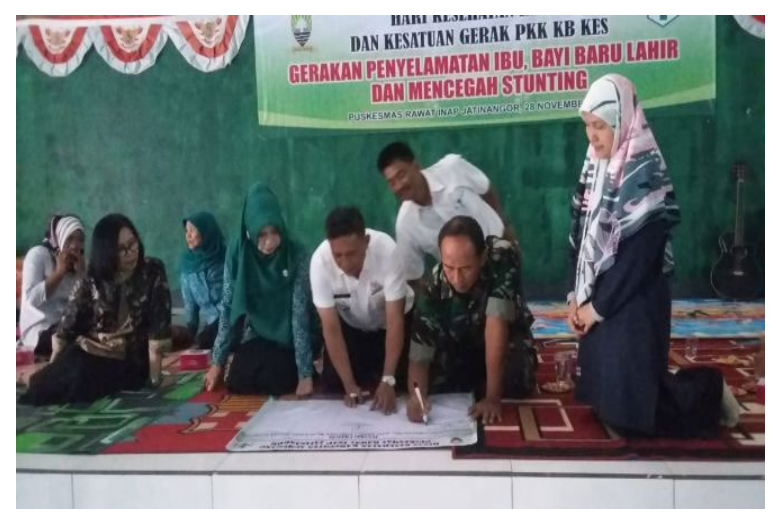

Gambar 5. Penandatanganan komitmen pencegahan stunting oleh Camat Jatinangor disaksikan ibu Kepala Puskesmas Jatinangor (paling kanan)

\section{DAFTAR PUSTAKA}

Arrish, J., Yeatman, H., \& Williamson, M. (2017). Midwives' Role in Providing Nutrition Advice during Pregnancy: Meeting the Challenges? A Qualitative Study. Nursing Research and Practice, 2017(July), 1-11. https://doi. org/10.1155/2017/7698510
Kemenkes. (2012). Gizi Ibu \& Anak. Unicef Indonesia, Oktober 20(Gizi Ibu \& Anak).

Kemenkes. (2013). RISET KESEHATAN DASAR 2013. Referensi. https://doi.org/1 Desember 2013

Kementrian Desa. (2017). Buku Saku Stunting Desa Dalam Penanganan Stunting. Jakarta.

Kementrian Kesehatan RI. (2016). Situasi balita pendek. Info Datin, 2442-7659. https://doi.org/ISSN 24427659

Kusumawati, E., Rahardjo, S., \& Sari, H. P. (2015). Model Pengendalian Faktor Risiko Stunting pada Anak Bawah Tiga Tahun. Kesmas: National Public Health Journal, 9(3), 249. https://doi. org/10.21109/kesmas.v9i3.572

Maywita, E. (2018). Faktor Risiko Penyebab Terjadinya Stunting Pada Balita Umur 12-59 Bulan Di Kelurahan Kampung Baru Kec . Lubuk Begalung Tahun 2015. Jurnal Riset Hesti Medan, 3(1), 5665 . 